\title{
Chapter 4 \\ School, Languages and Power in Pretend Play of Romani Children
}

\author{
Pavel Kubaník
}

\begin{abstract}
This text explores different language ideologies and different ideologies of childhood and socialization among Romani parents and local teachers of Romani children. It also makes some notes on different modes of learning that the children can come across both inside and outside the school environment. All these features can be linked with the child-structured pretend play with school instruction as the main topic, as I observed it during my stays in one segregated Romani settlement in Eastern Slovakia. Among other functions, this play creates a natural niche of using Slovak, a language of instruction and the second language of children in Gav, which is not used in home environment of the children. I will show that, despite the teachers seeing the Romani settlement as a non-stimulating environment, the children learn many things in many different patterns. Nevertheless, the text presents the settlement and the school not as two different worlds, but as places naturally linked together through child agency.
\end{abstract}

Keywords Language socialization · Second language acquisition · Romani · Slovak · Child play

\section{Introduction}

One of the possibilities of securing equal access to education in states with substantial language minorities is enabling education of minority children in their mother tongue. Although this is an option also in Slovak legislation, it is very rare when teachers or their assistants in Slovak schools attended by Romani speaking children have some knowledge of the children's language (Office of Public Defender of Rights 2013, pp. 23-24).

\footnotetext{
P. Kubaník $(\bowtie)$

Department of Central European Studies, Faculty of Arts, Charles University, Prague, Czech

Republic

e-mail: pavel.kubanik@ff.cuni.cz
} 
This article is a short case study from a locality, where local school is attended only by Romani children from spatially, socially, symbolically and infrastructurally excluded locality. While all of the pupils in the local school were native speakers of Romani, the language of instruction at the school was Slovak. In this article I will try to focus on how teachers, parents and children deal with this practice.

I will point at different ideologies of childhood and socialization between Romani parents and local teachers of Romani children, I will make some notes on different modes of learning which the children can come across inside and outside the school environment and I will present the settlement and the school not as two different worlds (as they are sometimes portrayed by teachers), but as places naturally linked together through child agency.

\section{Romani Chilhoods in Academic Discourse}

Studying different childhoods became a visible trend in sociology and anthropology especially in last two or three decades (Corsaro 2005; LeVine and New 2008; Montgomery 2009; Wells 2017). One characteristic feature of these studies is that they don't take children as containers into which outer knowledge of more experienced people is poured, quite reversely, children are understood in these paradigms as actors, which take part in (their) socialization. One possible facet of their agency in socialization is that they socialize their caretakers into caretaking roles (for example grandfather socializes his granddaughter, but also the granddaughter takes part in socializing the man into the specific social role of grandfather). Another facet could be seen in the mutual socializing role of children in peer collectives or groups of children of different ages.

The most common context in which Romani childhood is studied so far is school education. Bittnerová (Bittnerová et al. 2011, pp. 122-123) for instance, notes that in Czech academic literature on Romani children and socialization, most of the studies focus on (non)compatibility of socialization in schools and in Romani families. The character of Romani childhoods is thus studied almost exclusively through the lens of a preset pattern of education in school. Only a few texts focus on emic concepts of childhood and socialization (Bittnerová et al. 2011, 2017) or give voice to Romani children themselves or study their agency (Tauber 2004; Viková 1996; Engebrigsten 2007).

This feature of academic discourse mirrors more general inequalities that can be found in teachers' discourse as well. During my fieldwork in Slovakia the open letter of teachers from Eastern Slovakia was published (Polgáriová and Liptáková 2012), in which its authors expressed their complaints to the Minister of Education about insufficient support for teachers who teach Romani pupils who grow up in poor Romani settlements. The letter portrayed Romani families as units without any socializing function, i.e. socialization in Romani families was not taken as simply different, but as completely absent. 
In this article I will focus on second language (L2) socialization and I will show how this facet of socialization is experienced and performed by parents, teachers, and children themselves.

\section{Methodology}

My chapter works with data that I gathered during repeated shorter fieldwork stays in the Romani settlement Gav (the name is changed) in Eastern Slovakia during 2012-2013 where I spent 5 months in total. The main focus of my research was language socialization (see below). During the fieldwork I was gathering audio and video recordings of social interactions between children and people in their surroundings. At the beginning of my research I knew the locality and its dwellers already for 8 years, during which I was in regular contact with them. Besides the research in the settlement itself, I had an opportunity to observe instruction in the preparatory class in the local school in September 2013 for 1 week, i.e. I was enabled to observe one of the first days of a group of 6 years old children from Gav in school. I had also the opportunity to informally speak with and to interview local teachers.

The basic theoretical framework of my research in Gav was language socialization. Language socialization is based on a precondition that language and socialization are multiply interconnected processes (Ochs and Schieffelin 1984) —children learn to use language as social means to reach different goals (to make a joke, to ask someone, to object) through their participation in everyday socially structured activities. On the other hand, language works as a basic medium of socialization of children and other novices. Research in language socialization focuses on repeated everyday interactions of children with their caretakers and other people in their surroundings and links conversation analysis of these interactions with broader concepts of the particular culture. Language socialization explores how these concepts permeate and structure everyday interactions with children and by doing so it addresses topics of the relation between language and culture, culture transmission and change.

In this chap. I will use also theoretical categorization of patterns of learning (Rogoff et al. 2007). Rogoff and her collaborators pay attention to social organization of situations, in which children learn (flexibility of roles, how much learners can participate), purpose of these situations both for learners and for advanced participants, means of learning, kind of communication during these situations and kind of assessment that learners can obtain. On the basis of these facets they recognize three basic models of learning - intent community participation, assembly line instruction and guided repetition. This theory points to a variability of situations and ways of learning new things in life and understands classic school instruction just as one specific way of learning children encounter during their life. In the following text I will show that children in Gav experience all these basic kinds of learning and that some of the learning situations are initiated and structured by the children themselves. 


\section{Ideologies of Language (and Socialization)}

The primary language of communication and socialization in Gav is Romani, or more precisely, one of its Northern central varieties [see Elšík and Beníšek (2020) for overview of Romani dialects classification]. The language of instruction at local school is Slovak. Children are exposed to Slovak from an early age through media or when accompanying their parents when they leave the ethnically segregated settlement etc. Only some of the children attend local kindergarten (often irregularly). Most of the children enter preparatory (or zero) class by the age of 6 . The school is attended only by children socialized in Romani, teachers are only non-Roma whose competence in Romani is limited only to a few basic words or phrases. According to the local teachers most of the children are not competent in Slovak when they start the preparatory class. Better competence in Slovak is observed only if the children attended kindergarten regularly-however in time of my fieldwork the capacity of the local kindergarten was not sufficient for including all of the children who were born in the settlement during 1 year.

According to the teachers it is the parents who are responsible for the competence of their children in Slovak. Before my research started, the school was running a project focused on teaching the parents Slovak poems and nursery rhymes. The parents were supposed to teach these pieces of Slovak their children and thus to establish some foundations on which further competence in Slovak can be built upon. Short poems and nursery rhymes were also one of the initial activities of lessons in preparatory classes, which I had an opportunity to observe.

The teachers took Romani as a language with a restricted number of concepts that is less important for the future of the children than the Slovak language. This view was a part of a broader teacher's concept of the settlement as a non-stimulating environment. "Non-stimulating environment" was a short-cut term for the fact that the teachers were not able to identify features in the life of their pupils outside school which they would recognize as prerequisites of "normal" secondary socialization in school. The children from the settlement don't have any experience with texts, they are not led to use pencils and pens, "the only thing they have is a ball". According to the head master, the children from Gav "do not come into contact with real life". Implicitly, the real life awaits only outside the segregated environment. The goal of the school instruction is to prepare children for this life "outside", which is also part of the motto the school uses in its materials: "We learn for life". It is important to notice, that the teachers (as any other non-Roma) do not visit the settlement and their knowledge of the life of the children is based on what they can hear from the children in school and what they can infer from children's behaviour in school. Although this experience can be quite substantial, the general mindset of the teachers was that the environment of the children did not offer enough stimuli and these have to be imported from the outside. It is also important to notice that the children in the settlement of course live their real lives full of various stimuli. Chances for life out of the settlement were on the other hand limited by many social barriers. For instance, until recently not a single Romani family was enabled to buy a house in the village, 
although Roma were citizens of the village for more than 100 years. Ethnic segregation is also one of the basic limits for the acquisition of Slovak in pre-school period.

To a certain extent the school is open to multicultural discourse-it celebrates the International Day of Romani, the International Day of the Roma, it involves pupils in other initiatives supporting Romani. On the other hand, this position of Romani at the school is limited by these extraordinary events. It is characteristic for the everyday operation of the school with only L1 Romani pupils that the instruction is in Slovak, teachers don't know Romani and they refuse the possibility of learning Romani as an improportional intervention into established relationships between pupils and teachers ("the children could took advantage of our competence in Romani and they would not strive for learning Slovak"), competence in Romani is not a criterion for a position of the assistants to the teacher who are part of teacher's collective at the school, and some of the teachers also claimed that they stop children from using Romani even during school breaks. By these processes the school is active in maintaining the borders between the Romani and non-Romani environment.

Although the teachers described the competence of the children in Slovak in the first months of their school attendance as practically non-existent (with the exception of several children who were attending kindergarten), in our group interview about limits and the potential of the children the language barrier was not mentioned at all (maybe because it was too obvious). However, bilingualism of the children was not mentioned as a possible asset either (maybe the reason here was that, as in case of many other bilingual children, their bilingualism did not correspond to the ideal balanced type; see Wei 2000 for categories of bilingualism). Nevertheless, during the lessons in the preparatory class that I was allowed to observe, i.e. during the first days of children's school attendance, the teachers were speaking Slovak, which means they had to presuppose that the children (or at least part of them and to a certain degree) are able to understand Slovak. The children accepted the language rules of instruction and they took part in the lesson by responding individually or (more often) in groups to easy questions by the teacher. In this sense they took part in letting the instruction flow and were confirming the social position of the teacher (had they not reacted, they would have challenged the teacher's role). Sometimes children who were more competent in L2 served as interpreters for their less L2 competent classmates-sometimes they were asked by their teachers to translate, more often they did it on their own initiative.

Concerning the style of communication during the lessons in the preparatory class, it had a clear structure of multiple initiation-response-follow up sequences in which the teacher asked simple questions ("what is this called?"), children responded ("paper"), teacher controlled the answer ("yes, this is paper") and went on to another question or task ("and now we will draw some lines") which (s)he again controlled and supervised its fulfillment ("not that way, do it like this"). The teacher segmented the final knowledge (for example writing) into subsequent steps (drawing lines, drawing circles etc.). The real goal of these delimited steps could not be comprehensible for the pupils on their own. Children had very limited opportunity to 
intervene into the teaching process and to collaborate on its development. This was caused also by language barrier. A simple knowledge of politeness routines of Slovak (addressing the teacher with pani učitelka "Mrs. teacher") could lead to a possibility of asking something out of the set of the instruction. However, not all children knew or were able to use this simple technique during their first school days.

As I've already noticed, teachers took Romani parents as a key actors of socialization of their children, including second language socialization (despite the fact that the Roma live segregated from native speakers of Slovak). However, in the daily practice of the settlement not only parents, but also children and other adults were important actors of socialization. Parents took children from 3 or 4 years as those who can already take over some part of the daily care of the younger children-they could play with them, make fun with them or comfort them when it was needed. As children grew older, also their socializing competence and tasks were higher. Children of an early school age not only played with younger children, they could also carry them and help their pregnant mothers or aunts when they couldn't carry their child on their own. It is important to notice that children in Gav had confidence in responsibly carrying out these tasks from their surroundings. Older children were able to help younger ones in different ways, especially girls could cook some basic food; 7 year old children (i.e. in the age of the beginning of school attendance) were already commonly left alone to care for much younger siblings. They had confidence to do it and they could learn through their participation in these socioculturally structured activities.

Second language acquisition fits very well into this context. Romani parents took the school as a place where their children will learn Slovak. Parents didn't teach their children Slovak, although they intentionally prepared them for school enrollmentthey taught them questions and words in Slovak which they would need to know to answer correctly (names for colours or animals, their name, age...). As a kind of motto or refrain in these functional language activities I see the Slovak request Pani učitelka, prosím si na záchod "Mrs. teacher, I need to go to the toilet". Parents in Gav (but also in several other Romani settlements I have visited) took this polite request as very substantial because it could save their children from being disgraced in the eyes of their classmates and teachers. However, siblings, cousins and friends, who were already attending school were also involved in the development of such preparatory strategies for pre-school children. Both parents and preschoolers in Gav were saying that children can learn the basics of Slovak from other children. In the segregated environment of the Romani settlement with close to $100 \%$ unemployment and restricted contacts to the outer world, at least in time of my research, it was to a great extent the Romani pupils who were most regularly (almost daily) crossing the border between the Romani settlement and non-Romani village. It was the children of school age who most often had to use Slovak actively on a daily basis. And it was children of a school age who were transmitting their (language) experiences naturally into their households and were spreading it in peer collectives in which they were spending most of their free time. 


\section{Playing the Books}

During my fieldwork visits in Gav, I've regularly encountered with child-structured role plays, which Romani children themselves called te bavinel kňiški "to play the books". In my view, playing the books, a play with school instruction as the main topic, can be taken as an essence of children's agency in L2 socialization, although it wasn't the only situation in which the local Romani children were playing with their language repertoires including features of Slovak.

The topic of pretence during "playing the books" was school instruction. Both "pupils" and "teachers" were speaking Slovak during this pretend play, although their mother tongue or the language which was almost exclusively used during interactions in the settlement was Romani. Concerning this language environment, "playing the books" served as an important niche of the second language acquisition, which was structured and performed by the children themselves. During this particular pretend play, even 3 year old children showed they were able to respect the sociolinguistic norm of using languages in their speech community to a certain degree. Adult Roma in Gav are all at least bilingual and they use Slovak also within Romani based discourse, especially in reporting utterances of non-Roma (which is a very common function of code-switching in bilingual communities, see Gumperz 1982). This type of speaking and code switching forms also a natural part of children's language socialization. Therefore, because the instruction in school runs in Slovak, the children also use this language (or at least are trying to use it as much as they can) when they are taking on roles of teachers and pupils during play [see also Réger (1979) for a similar case of Romani children in Hungary].

The mere designation of the play is significant. It shows, that the play was played so many times, that an appellation could be established (I observed this play during all of my fieldwork visits in Gav). The name of the game also does not mention school as such, establishing books as a synecdoche for the school, i.e. selecting a typical object which is in the view of the children linked only with school (I haven't seen books in the Gav households except for the Bible in the families of several members of the Pentecostal church). This goes partly in line with the observation of the teachers that the children do not have contact with texts in the pre-school period but also undermines the supposed "lack of various stimuli" in the children's daily routines in Gav. What is more, it shows that schoolchildren in particular can mediate some kind of contact with texts to pre-school children.

Playing the books [see Kubaník (2015) for detailed linguistic description of these interactions] is played by a collective of four to ten children, in which both school and pre-school children participate. Some children take up the role of teachers, the other ones perform pupils, the game can last over an hour. Within the play children keep the rule to speak (or at least try to speak) only Slovak, i.e. to use language which is used in school. Switching into Romani is taken as a marker of out-of-frame sequences, i.e. speaking about the play or stepping out of it (for example when one of the players asks for something his/her mother who is passing by at the moment). Aside from the language it is also the broader context of coexistence of the school 
and its pupils from the settlement which becomes part of the pretend play. Child teachers are asking about kinship relations between their pupils, they reprimand them for not being neat, ask them if they already brought money for school lunches and snacks, they use only the official first names of the children, not used when children are addressed in the settlement as other than official first names are routinely used in daily communication. Child teachers not only use Slovak, but speaking in the role leads them to use features of Slovak teacher talk register (for example deictic shift you > we, for example in the teacher's utterance Prve mame pisanie "As first we have writing"; see also the example from school lessons above in this article), pupils use Slovak politeness routines, which are used in school but not in the settlement and which don't have clear equivalents in Romani discourse. One of the first and most simple utterances used by the youngest players is addressing the teacher politely with pani učitelka "Mrs. teacher", only after which they voice their requests, which can be expressed without words or with a little help from children, who are already more competent in Slovak. School children also practice and teach pre-school children to hold a pencil or to draw a line or a circle, i.e. practical skills which are examined already in school enrolment.

\section{Modes of Learning}

From this brief summarization it is easy to infer that 6 year old children in Gav have experience with different modes of learning. They learn their mother tongue or how to take care of small children within "intent community participation" pattern. They have an opportunity to observe activities around them, they have some leeway to try new things not through some abstract exercises and words, but through their own participation in shared activity. People in their surroundings give children some confidence, which partially mirrors community or traditional aspects of the pattern in certain contexts. More experienced children can correct the other children, and children get direct assessment within shared activity.

Other examples mentioned above are close to the "guided repetition" model. The teachers recommend to the parents to teach their children Slovak nursery rhymes and sayings, children learn important Slovak words and phrases by repeating them after their caretakers and they can use them within school enrolment, teachers use the sayings at the beginning of lessons in preparatory classes as a foundation for further development of competence in Slovak and mutual communication between the teacher incompetent in Romani and children not competent enough in Slovak.

During school lessons children are participating in the "assembly line instruction" pattern-means of learning are basically words, the instruction is structured and led by the teacher, knowledge is divided into separate exercises that pupils have to fulfill.

I take this general categorization as a useful framework because it enables us to see one important feature of playing the books. The pretend play is working with the image of "assembly line instruction"- for example roles of teachers and pupils to a 
certain degree paraphrase different power of these actors in reality. However, the children change the initial image into an "intent community participation" model. As opposed to the school, children who play the books have leeway to improvise, they participate in a shared activity (for example by keeping the rule to speak Slovak) and can change course of the play through their activity.

\section{Conclusions}

In the text above I chose several ethnographical vignettes (child-structured pretend play, children's caretaking routines, agency of children during school instruction) to point out the fact that children are not only objects of (primary and secondary) socialization, but also its subjects or actors with their own agency, which is sometimes overlooked.

For example, although the teachers noticed some aspects of peer group socialization (younger children from the same families often have better results; younger children from the same families often come to preparatory classes and already know some school activities), they did not view them as important. They took parents as the only actors of socialization and therefore they were trying to influence their behaviour towards preschool children, although they already experienced influence of peer group socialization. Child agency was overlooked also in cases when children were practically helping the teachers-for example when more competent children served as interpreters between the teacher and the children who were not able to understand Slovak. Although this was happening quite often during the lessons, teachers perceived the children basically uniquely as pupils "incompetent in Slovak" or rather as the only participants of mutual interaction who have communication problems.

The school in a segregated environment has a great potential to reach over the ethnic borders especially through its contact with school children, who are crossing these borders almost every day. On the other hand, there is also a potential of school to strengthen these borders. In case of Gav and the local school, this process can be identified in the fact that the school takes the settlement as "non-stimulating environment" and sets its goal of the instruction as to prepare the children for "real life" outside the settlement. The second example of this power imbalance is that Romani, the mother tongue of all of the pupils, has merely an emblematic function in the school. After all, the practice of playing the books can be interpreted as an evidence of the fact, that the children very quickly (even in a pre-school age) internalize the school environment as a non-Romani one-the books are played automatically in Slovak, the particular language is connected with the school in the same direct way as the books, which we can find in the name of this particular activity.

The play can be perceived as a child-structured means of resilience, or a way to cope with stress which results from leaving the safe ground of family relationships, language and culture and entering the "new world of school". On the other hand, the play also shows that although the teachers by their ideology delimit the borders 
between the settlement and the school, the school is part of the lives of the Romani children in Gav and it is incorporated into their everyday activities. The school and the settlement are not so strictly delimited entities.

Although I built this chapter to a certain degree upon my critical notes on ideologies of particular teachers in one particular school, it is important to note that the school serves here more as an image or self-reproduction of the system, within which the teachers themselves experience their socialization, primary (in their families) as well as secondary (in schools and at university departments). School is an integral part of the system and to overstep its paradigms would mean to overstep commonly shared values and hierarchies (for example who, what and from whom can learn something). In this respect, the telling detail is that the school with pupils who are all socialized in Romani has the same curriculum as if the children were native speakers of Slovak (although due to a large Hungarian speaking minority living in Slovakia, there exists a program for teaching Slovak as a second language). The teachers explicitly expressed their unwillingness to learn Romani and to overstep established power hierarchies. The school strengthens this hierarchy also by the fact that competence in Romani is not demanded even from pedagogical assistants, i.e. employees who should serve as mediators between teachers and pupils with any learning problems. Parents of the children on the other hand respect the hierarchy by not demanding instruction in Romani, which is their right in Slovakia (although it is possible they do not even know that such a right exists). In this respect, the language ideologies that can be found in one school only mirror more general language ideologies in Slovakia as a state where (only) Slovak should be spoken.

Despite all of this, I took the teachers in the school in Gav, and especially its headmaster, as people who were ceaselessly trying to find new ways of educating local Romani children, although they were facing very difficult conditions. As one of the ways that can be tested in future that I can offer on the basis of my experiences is to take advantage or seek inspiration from the socializing potential of peer groups in the Romani settlement. The other way that can open some new possibilities is to overlook the image of the settlement as a merely non-stimulating environment, or, more generally speaking, to try to see the life of the children outside the school (including their language) as something inspirational for the school curriculum.

Acknowledgments I would like to thank Marián Sloboda, who helped me better express some of conlusions and Helena Sadílková and Mark Payne for English proofreading.

The work was supported by the European Regional Development Fund-Project "Creativity and Adaptability as Conditions of the Success of Europe in an Interrelated World" (No. CZ.02.1.01/0.0/ 0.0/16_019/0000734), by the Charles University project Progres Q10, Language in the shiftings of time, space, and culture and by the project Romani language repertoires in an open world (Riksbankens Jubileumsfond M18-0113-18).

\section{References}

Bittnerová, D., Doubek, D., \& Levínská, M. (2011). Funkce kulturních modelů ve vzdělávání. Praha: Fakulta humanitních studií Univerzity Karlovy v Praze. 
Bittnerová, D., Doubek, D., \& Levínská, M. (2017). Zápas o štastné dětství. Romano džaniben, 1 (22), 15-45.

Corsaro, W. A. (2005). The sociology of childhood. Thousand Oaks: PineForge Press.

Elšík, V., \& Beníšek, M. (2020). Romani Dialectology. In Y. Matras \& A. Tenser (Eds.), The Palgrave handbook of Romani language and linguistics (pp. 389-428). Cham: Palgrave Macmillan.

Engebrigsten, A. I. (2007). Exploring Gypsiness. In Power, exchange and interdependence in a Transylvanian Village. New York, Oxford: Berghahn Books.

Gumperz, J. J. (1982). Discourse strategies. Cambridge: Cambridge University Press.

Kubaník, P. (2015). Hra na knížky. Poznámky k akvizici slovenštiny v Gavu. In T. Podolinská \& T. Hrustič (Eds.), Čierno-biele svety. Rómovia v majoritnej spoločnosti na Slovensku (pp. 374-397). Bratislava: Ústav etnológie SAV, VEDA.

LeVine, R., \& New, R. S. (2008). Anthropology and child development. A cross-cultural reader. Malden, Oxford: Blackwell.

Montgomery, H. (2009). An introduction to childhood. Anthropological perspectives on Children's lives. Malden, Oxford: Wiley-Blackwell.

Ochs, E., \& Schieffelin, B. B. (1984). Language acquisition and socialization. Three developmental stories and their implications. In R. A. Schweder \& R. A. LeVine (Eds.), Culture theory: Essays on mind, self, and emotion (pp. 276-322). New York: Cambridge University Press.

Office of Public Defender of Rights. (2013). Správa verejnej ochrankyne práv o uplatňovaní práva na vzdelanie detí/žikov príslušníkov rómskej národnostnej menšiny so špeciálnymi výchovnovzdelávacimi potřebami [Report of Public defender of rights on implementation of right for education of children/pupils from Romani minority with special educational needs]. Bratislava: Office of Public Defender of Rights.

Polgáriová, E., \& Liptáková, E. (2012). Otvorený list učiteliek z východného Slovenska. Retrieved from http://janmacek.blog.sme.sk/c/301577/Otvoreny-list-uciteliek-z-vychodneho-Slovenska. html\#ixzz1zWjGqCWY. Visited November 11, 2018.

Réger, Z. (1979). Bilingual gypsy children in Hungary: Explorations in "natural"second-language Acquisition at an Early age. International Journal of the Sociology of Language, 19(5), 59-82.

Rogoff, B., Moore, L., et al. (2007). Children's development of cultural repertoires through participation in everyday routines and practices. In J. E. Grusec \& P. D. Hastings (Eds.), Handbook of socialization: Theory and research (pp. 490-515). New York: The Guilford Press.

Tauber, E. (2004). Sinti Estraixaria children at school, or, how to preserve 'the Sinti way of thinking'. Romani Studies, 14(1), 1-23.

Viková, L. (1996). Př́íspěvek $k$ poznání psychologických aspektů romské rodiny (srovnávací výzkum romské a neromské rodiny z pohledu 9-10 -tiletých dětí). Diplomová práce. Praha: FF UK, Katedra psychologie.

Wei, L. (2000). Dimensions of bilingualism. In W. Li (Ed.), The bilingualism reader. London, New York: Routledge.

Wells, K. (2017). Childhood studies. Cambridge: Polity Press.

Open Access This chapter is licensed under the terms of the Creative Commons Attribution 4.0 International License (http://creativecommons.org/licenses/by/4.0/), which permits use, sharing, adaptation, distribution and reproduction in any medium or format, as long as you give appropriate credit to the original author(s) and the source, provide a link to the Creative Commons licence and indicate if changes were made.

The images or other third party material in this chapter are included in the chapter's Creative Commons licence, unless indicated otherwise in a credit line to the material. If material is not included in the chapter's Creative Commons licence and your intended use is not permitted by statutory regulation or exceeds the permitted use, you will need to obtain permission directly from the copyright holder.

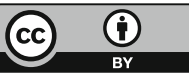

